\title{
Physicochemical changes during the different stages of dry cured lamb ham processing
}

\section{Alterações físico-químicas em diferentes etapas do processo de cura a seco de presunto ovino}

\author{
Adriana Isabel Rada Bula ${ }^{1 *}$, William Albarracín Hernández², Manuel Fernando Ariza Botero³ \\ ${ }^{1}$ Universidad del Atlántico, Facultad de Ingeniería, Atlántico - Colombia \\ 2Universidad de Nariño, Facultad de Ingeniería Agroindustrial, Pasto/Nariño - Colombia \\ ${ }^{3}$ Universidad Nacional de Colombia, Departamento de Producción Animal, Bogotá D.C. - Colombia
}

\section{*Corresponding Author}

Adriana Isabel Rada Bula, Universidad del Atlántico, Facultad de Ingeniería, 081007, Atlántico - Colombia, e-mail: aradabula@mail.uniatlantico.edu.co

Cite as: Physicochemical changes during the different stages of dry cured lamb ham processing. Braz. J. Food Technol., v. 20, e2016036, 2017.

\section{Abstract}

The aim of this study was to evaluate the main changes that occur during dry cured lamb ham processing using lamb shanks (Dorper $\times$ Camuro crossbreed). For this purpose the physicochemical parameters were evaluated in each stage of the process (salting, post-salting and drying-ripening) at different test times, testing after $0.7,1.0$ and 1.2 days $/ \mathrm{kg}$ in the salting phase; 0,15 and 30 days in the post-salting phase; and 3 and 6 months in the drying-ripening phase. Each analysis was carried out in different zones of the meat piece (zone A near the lean meat; zone B near the bone; zone $\mathrm{C}$ near the fat covering; zone $\mathrm{R}$ as a mean). The results suggested that the salting times had a similar behaviour on the physicochemical parameters. The 0.7 days $/ \mathrm{kg}$ phase showed the same value reported for this kind of product. In the post-salting stage there were significant differences between the times tested. A chemical balance was found as from day 15, when similar salt contents were found, indicating homogenous values for the salt concentration between each zone. Finally, the drying-ripening results showed there were no significant differences for each physicochemical parameter between the times evaluated, but there were significant differences with respect to the beginning of the process.

Keywords: Salting; Post-salting; Drying - ripening.

\section{Resumo}

O objetivo deste estudo foi avaliar as principais alterações que ocorrem durante a cura a seco do presunto feito de pernil dos ovinos (Dorper $\times$ Camuro). Com esse propósito, os parâmetros físico-químicos foram avaliados em todas as etapas do processo (na fase de salga, pós-salga e maturação), em diferentes tempos de teste. Cada análise foi realizada em diferentes zonas das peças de carne (zona A, perto da área magra; zona B, perto do osso; zona C, perto da cobertura de gordura; zona $\mathrm{R}$, como uma média). Foram testadas a 0,7; 1,0; 1,2 dia/kg na fase de salga; de 0; 15; 30 dias na fase de pós-salga, e de 3 e 6 meses na fase de maturação. Os resultados sugerem que os tempos de salga tiveram um comportamento semelhante nos parâmetros físico-químicos. A fase de 0,7 dia/kg apresentou o mesmo valor reportado para este tipo de produto. Na fase de pós-salga, houve diferenças significativas entre os tempos testados. Foi encontrado um equilíbrio químico a partir do $15^{\circ}$ dia, quando teores semelhantes de sal foram encontrados. Isso indica valores homogêneos para concentração de sal entre cada zona. Finalmente, os resultados de maturação mostraram que não houve diferenças significativas para cada parâmetro físico-químico entre os tempos avaliados, mas houve diferenças significativas com respeito ao início do processo.

Palavras-chave: Salga; Pós-salga; Maturação. 


\section{Introduction}

Traditionally, the preparation of dry cured products has been used as a preservation method. Initially it was mostly pork pieces that were prepared using this method, but nowadays, the use of different species pieces such as bovine, buffalo and ovine are at the forefront to produce Bresaola, Tasajo and Cecina, respectively, and other dry cured products (ALBARRACÍN, 2009; SINHA, 2007)

Basically, the dry curing process includes the salting, post-salting and drying-ripening stages. During the salting stage, the meat piece adsorbs salt in the expectation that the product will acquire enough curing ingredients (mainly salt) to give the necessary microbiological stability as a bacteriostatic agent, reducing the water activity in the subsequent stages (ALIÑO et al., 2009a; BARAT et al., 2004, 2006; SINHA, 2007). During the post-salting stage, the meat piece reaches a chemical balance, where the $\mathrm{Na}^{+}$and $\mathrm{Cl}^{-}$ions acquired during the salting stage are distributed homogenously by a diffusion process from the external zones to the internal ones (ALIÑO et al., 2010; ARNAU et al., 1995). At the same time water transference takes place from the surface of the meat piece to the external environment (surface evaporation) due to convective drying (BOADAS et al., 2001). The drying-ripening stage corresponds to the last stage of the process, the main changes occurring being biochemical (proteolysis, lipolysis) and physicochemical (moisture variation and water activity). The water activity affects the chemical, enzymatic and microbiological kinetics that control this stage (TOLDRÁ, 2002).

A variety of dry cured mutton products are produced in the world. Products such as Pastrma, Stelja and Kastradina are produced in the Center and North of Europe (STOJKOVIĆA et al., 2015), each product showing a strong traditional component (VILLALOBOS DELGADO et al., 2014) and using different meat pieces and processes, some using entire pieces and the smoking process. Fenalår is another dry cured product produced in Norway (TOLDRÁ, 2014), with the particularity that it is made with mutton legs, and various mutton products have been developed in America (TOLDRÁ, 2014). However, there are few publications with respect to the physicochemical changes that occur during the processing of this kind of product (GANIĆ et al., 2013; TROEGER et al., 2009; KRVAVICA et al., 2009; OPERTA et al., 2010; STAMENKOVIĆ; DEVIĆ, 2006; PALEARI et al., 2006; STOJKOVIĆA et al., 2015; VILLALOBOS DELGADO et al., 2014). The aim of this study was to analyse the main physicochemical changes such as mass variation, salt and moisture content and the water activity in the different zones of the meat piece during the development of a dry cured lamb product.

\section{Material and methods}

Forty five Dorper $\times$ Camuro lamb shanks each weighing $2.47 \mathrm{~kg} \pm 0.36 \mathrm{~kg}$ were selected from the same farm from animals with an average age of 4 months and with a $24 \mathrm{~h}$ post-mortem $\mathrm{pH}$ value of between 5.6 and 6.0. The $\mathrm{pH}$ measurements were made using a $\mathrm{pH}$ meter HANNA $^{\circledR}$ model $\mathrm{HI}$ 99161, and the shanks were then stored at $-18.0^{\circ} \mathrm{C} \pm 1.0^{\circ} \mathrm{C}$ until processed. Three shanks were used for the characterization of the raw material or control. Nine shanks were used for the salting stage, nine for the post-salting stage and twenty four for the drying-ripening stage. The shanks were thawed in a cold chamber $\left(4.0^{\circ} \mathrm{C} \pm 1.0^{\circ} \mathrm{C}\right)$ until the internal temperature rose $5.0^{\circ} \mathrm{C} \pm 1.0^{\circ} \mathrm{C}$ when the excess fat and glandular tissue on the internal side of the piece meat were removed. The pieces were then nitrified with a dry salt mixture of $\mathrm{NaNO}_{2}$ and $\mathrm{KNO}_{3}$ at $150 \mathrm{ppm}$ and $300 \mathrm{ppm}$, respectively. After $24 \mathrm{~h}$ the shanks were covered with salt for $0.7 ; 1.0$ and 1.2 days $/ \mathrm{kg}$ (average shank weight) with a temperature of 3.0 to $5.0^{\circ} \mathrm{C}$ and $95 \% \mathrm{RH}$. They were then washed and divided for the physicochemical analyses. In the post-salting stage, the salting process was repeated for 0.7 days $/ \mathrm{kg}$ and the shanks were then hung in a drying room with a temperature from $5.0^{\circ} \mathrm{C}$ to $10^{\circ} \mathrm{C} \pm 2.0^{\circ} \mathrm{C}$ and a relative humidity from $90-95 \%$ to $80 \%$ for 0,15 and 30 days. At the end of the process, they were washed and divided for the physicochemical analyses. The salting and post-salting stages for the drying and ripening stage using 0.7 days $/ \mathrm{kg}$ and 15 days respectively. During this period, 24 lamb shanks were used and divided into two groups: 3 and 6 months (named as $3 \mathrm{M}$ and $6 \mathrm{M}$ respectively). The $3 \mathrm{M}$ group was evaluated after $0,1,2$ and 3 months (0/3M; 1/3M; 2/3M and $3 \mathrm{M}$ ) and the $6 \mathrm{M}$ group after $0,2,4$, and 6 months (0/6M; 2/6M; 4/6M; 6M). Both groups were submitted to temperatures of from $10.0^{\circ} \mathrm{C} \pm 2.0^{\circ} \mathrm{C}$ to $29.0^{\circ} \mathrm{C} \pm 1.0^{\circ} \mathrm{C}$ and a relative humidity of from $80 \%$ to $75 \%$.

\subsection{Physicochemical analyses}

The initial and final weights of each lamb shank were measured to determine the mass variation $(\Delta M)$ where $M_{f}$ and $M_{i}$ correspond to the final and initial masses $(\mathrm{kg})$ respectively (Equation 1) (BARAT et al., 2005). The water activity $\left(a_{w}\right)$ was determined using a water activity meter HygroLab C1 (Rotronic, USA). The water content ( $X^{w}$ b.s.) was determined in a drying oven at $105.0^{\circ} \mathrm{C}$ to constant weight (ISO, 1973). The $\mathrm{NaCl}$ content was determined by homogenizing 3.0 to $5.0 \mathrm{~g}$ of ground sample with distilled water using an Ultraturrax T25. Subsequently, the solution was filtered and brought to a known volume with distilled water and a $20 \mu \mathrm{L}$ aliquot of taken for analysis in the SAT-500 brand TDA-DK chloride analyser. The salt mass fraction ( $\mathrm{X}^{\mathrm{NaCl}}$ b.s.) was expressed as $\mathrm{kg}$ of $\mathrm{NaCl} / \mathrm{kg}$ sample on a dry weight basis, free of fat and salt for the salting stage. 
Physicochemical changes during the different stages of dry cured lamb ham processing

Rada Bula, A. I. et al.

To compare the post-salting and drying-ripening stages, the data were expressed as $Z^{\mathrm{NaCl}}$ (Equation 2).

$$
\begin{gathered}
\Delta \mathrm{M}=-\frac{\left(\mathrm{M}_{\mathrm{f}}-\mathrm{M}_{\mathrm{i}}\right)}{\mathrm{M}_{i}} \\
\mathrm{Z}^{\mathrm{NaCl}}=\frac{\mathrm{X}^{\mathrm{NaCl}}}{\mathrm{X}^{\mathrm{NaCl}}+\mathrm{X}^{\mathrm{W}}}
\end{gathered}
$$

\subsection{Sampling}

The water contents, water activity and sodium chloride contents were determined in four different zones taken from the widest section of the shank (under the coxofemoral joint up to $4 \mathrm{~cm}$ below): zone $\mathrm{A}$ near the lean meat, zone $\mathrm{B}$ near the bone, zone $\mathrm{C}$ near the fat covering and zone $\mathrm{R}$ as the mean (Figure 1.). Each analysis was carried out on in each lamb shank in the different zones and with three replications. The samples were stored at $5.0^{\circ} \mathrm{C}$ for no longer than $24 \mathrm{~h}$ for the water activity and moisture determinations. For the other analyses, the samples were stored at $-20{ }^{\circ} \mathrm{C}$ until the pre-determined time.

\subsection{Statistical analyses}

The analysis of variance (ANOVA) was used to analyse the zones and each time evaluated in each process stage $(p<0.05)$. The differences were tested using Fisher's Least Significant Difference (LSD) procedure and both analyses used the STATGRAPHICS Centurion XV - Version 2.15.06.

\section{Results and discussion}

\subsection{Salting}

In this stage, the $\mathrm{NaCl}$ content was expressed as $\mathrm{X}^{\mathrm{NaCl}}$ (kg NaCl/kg sample on a free-fat basis); and the results showed significant differences between the zones $(p<0.05)$ (Table 1). Zones A and $\mathrm{C}$ presented higher $\mathrm{NaCl}$
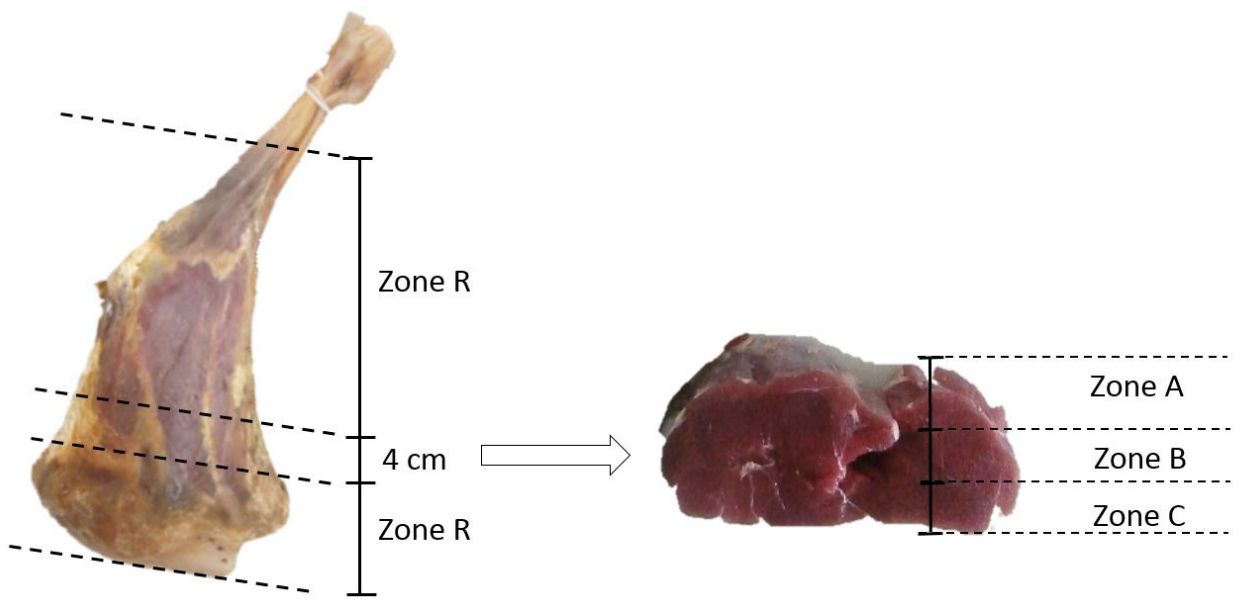

Figure 1. Sampling zones.

\begin{tabular}{|c|c|c|c|c|}
\hline \multirow{2}{*}{ Zones } & \multirow{2}{*}{ Parameters } & \multicolumn{3}{|c|}{ Sampling time } \\
\hline & & 0.7 & 1.0 & 1.2 \\
\hline \multirow{3}{*}{ A } & $a_{w}$ & $0.903 \pm 0.001$ & $0.907 \pm 0.005$ & $0.906 \pm 0.005$ \\
\hline & $X^{w}$ & $2.937 \pm 0.201$ & $2.773 \pm 0.164$ & $3.212 \pm 0.284$ \\
\hline & $X^{\mathrm{NaCl}}$ & $0.282 \pm 0.059$ & $0.294 \pm 0.031$ & $0.328 \pm 0.020$ \\
\hline \multirow{3}{*}{ B } & $a_{w}$ & $0.950 \pm 0.004$ & $0.949 \pm 0.004$ & $0.938 \pm 0.011$ \\
\hline & $X^{w}$ & $3.504 \pm 0.454$ & $3.066 \pm 0.165$ & $3.318 \pm 0.026$ \\
\hline & $X^{\mathrm{NaCl}}$ & $0.119 \pm 0.004$ & $0.147 \pm 0.018$ & $0.149 \pm 0.021$ \\
\hline \multirow{3}{*}{ C } & $a_{w}$ & $0.931^{a} \pm 0.005$ & $0.929^{a} \pm 0.005$ & $0.923^{b} \pm 0.007$ \\
\hline & $X^{w}$ & $3.109 \pm 0.078$ & $3.661 \pm 0.454$ & $3.129 \pm 0.094$ \\
\hline & $X^{\mathrm{NaCl}}$ & $0.255^{a} \pm 0.051$ & $0.289^{b} \pm 0.054$ & $0.241^{a} \pm 0.058$ \\
\hline \multirow{3}{*}{$\mathrm{R}$} & $a_{w}$ & $0.919 \pm 0.008$ & $0.925 \pm 0.005$ & $0.923 \pm 0.005$ \\
\hline & $X^{w}$ & $3.023^{a} \pm 0.092$ & $3.678^{b} \pm 1.338$ & $3.350^{\mathrm{ab}} \pm 0.103$ \\
\hline & $X^{\mathrm{NaCl}}$ & $0.242^{a} \pm 0.021$ & $0.243^{a} \pm 0.078$ & $0.277^{b} \pm 0.013$ \\
\hline
\end{tabular}

Table 1. Comparison between the different salting times - physicochemical parameters (mean values).

Sampling times: $0.7: 1.0$ and 1.2 (days $/ \mathrm{kg}): X^{\mathrm{NaCl}}$ expressed as ( $\mathrm{kg} \mathrm{NaCl} / \mathrm{kg}$ sample on a free-fat basis): Values with no letters in the same row are significantly equal at a $p$ value $<0.05$; Values with different letters in the same row are significantly different at a $p$ value $<0.05$. 
contents than zone B (inner zone) due to the proximity of these zones to the external regions of the meat piece. Zone A showed the highest value (Table 1) since this zone had no barrier such as fat or connective tissue that inhibited the absorption and subsequent diffusion of the salt within the meat piece (BELLO GUTIERREZ, 2012).

Comparing the $\mathrm{X}^{\mathrm{NaCl}}$ values at each evaluation time ( $A, B$ and $C$ ), no significant differences were observed $(p<0.05)$. Thus in this case, the time tested had no effect on this parameter during the stage, although Table 1 showed slightly lower values for the shorter testing times ( 0.7 and 1.0 day $/ \mathrm{kg}$ ). Some authors have suggested that the salt concentration depends on the time the stage lasted (BELLO GUTIERREZ, 2012; FULLADOSA et al., 2015).

In the same way, $X^{w}$ and $a_{w}$ showed a close relationship with $X^{\mathrm{NaCl}}$. Both parameters reached similar values between each evaluation time but registered statistical differences between the zones. For these two situations, zone $B$ showed higher values for $X^{w}$ and $a_{w}$ and zones $A$ and $C$ lower values. Thus the higher the water content the lower the $\mathrm{NaCl}$ concentration in this part of the process. This behaviour can be explained by the fact that the $\mathrm{NaCl}$ molecules retain water molecules, leaving the surfaces without available water, which is reflected in the lower $X^{w}$ and $a^{w}$ values (ALBARRACÍN, 2009).

\subsection{Post-salting}

In this stage there was a gradual increase in the $\mathrm{NaCl}$ content $\left(Z^{\mathrm{NaCl}}\right)$ in the inner zone (zone $\mathrm{B}$ ) and a decrease in the external zones ( $A$ and $C$ ) as a result of the diffusion of salt absorbed during salting, and the evaluation time significantly affected the salt concentration $(p<0.05)$ in each evaluation zone (Table 2). During the process, there was a tendency to equalize the chemical potential as determined by the salt/water ratio in the meat piece (BELLO GUTIERREZ, 2012). This was observed after 15 and 30 days, where the salt concentrations showed relatively close values in each zone $(A, B, C$ and $R$ ) although presenting significant differences $(p<0.05)$. Barat et al. (2005) found a similar behaviour in their studies with Spanish Ham, where the salt concentrations were different in each region evaluated (similar zones to those in the present study) although they applied a post-salting time commonly used in the Spanish Ham industry. These results were to the contrary of the general concept of a chemical balance occurring during this stage in dry cured products made with whole meat pieces (mostly pork), where the salt concentration is supposed to be uniform throughout the product, as cited by many authors (BELLO GUTIERREZ, 2012; BLESA et al., 2008; TOLDRÁ, 2014), such a condition for the $Z^{\mathrm{NaCl}}$ values reached during this stage allowing for product safety. The same authors also suggested that there are no published studies about a completely safe $Z^{\mathrm{NaCl}}$ value, due to a variety of factors such as the type of raw material, meat piece, processing technique used etc. Nevertheless they suggested that the post-salting stage can be considered to be finished when zone $B$ reaches a $\mathrm{Z}^{\mathrm{NaCl}}$ value near to 0.02 or higher.

In the present study, Table 2 shows that zone $B$ reached higher values after 15 and 30 days of post-salting. These results suggest that it is possible to obtain an appropriate salt concentration value in a short time of processing, allowing for a decrease in the microbiological risk during the subsequent stage (drying and ripening), while the ripening chamber conditions are changing (temperature increase and relative humidity decrease), at the same time as the values for $X^{w}$ and $a_{w}$ are decreasing. In this case, 15 days could be enough to reach a good $\mathrm{NaCl}$ concentration in the inner zone, and hence continue into the drying-ripening stage.

During post-salting, it was also observed that the $X^{w}$ in Zone B decreased with time, and after 15 and 30 days of post-salting, the values obtained were similar to those in zones $\mathrm{A}$ and $\mathrm{C}$ (Table 2). This can be explained by a process of osmosis taking place during this stage, where $X^{w}$ migrates to the external zones of the meat piece while $Z^{\mathrm{NaCl}}$ diffuses to

Table 2. Comparison between the zones at different post-salting times - physicochemical parameters (mean values).

\begin{tabular}{ccrrrc}
\multirow{2}{*}{ Sampling time } & Parameters & \multicolumn{4}{c}{ Zones } \\
\cline { 3 - 6 } & $a_{w}$ & $0.919^{\mathrm{a}} \pm 0.002$ & $0.950^{\mathrm{b}} \pm 0.002$ & $0.924^{\mathrm{a}} \pm 0.002$ & $0.930^{\mathrm{c}} \pm 0.005$ \\
0 & $X^{\mathrm{w}}$ & $2.943 \pm 0.198$ & $3.549 \pm 0.342$ & $3.098 \pm 0.170$ & $3.023 \pm 0.273$ \\
& $Z^{\mathrm{NaCl}}$ & $0.145^{\mathrm{d}} \pm 0.012$ & $0.025^{\mathrm{a}} \pm 0.004$ & $0.096^{\mathrm{c}} \pm 0.010$ & $0.066^{\mathrm{b}} \pm 0.006$ \\
& $a_{w}$ & $0.926^{\mathrm{a}} \pm 0.003$ & $0.934^{\mathrm{b}} \pm 0.005$ & $0.931 \pm 0.006$ & $0.926 \pm 0.004$ \\
15 & $X^{w}$ & $2.773 \pm 0.151$ & $3.035 \pm 0.155$ & $3.661 \pm 0.454$ & $3.207 \pm 0.667$ \\
& $Z^{\mathrm{NaCl}}$ & $0.073^{\mathrm{b}} \pm 0.002$ & $0.063^{\mathrm{a}} \pm 0.004$ & $0.065^{\mathrm{ab}} \pm 0.004$ & $0.072^{\mathrm{c}} \pm 0.027$ \\
& $a_{w}$ & $0.921 \pm 0.003$ & $0.930 \pm 0.002$ & $0.925 \pm 0.005$ & $0.922 \pm 0.004$ \\
30 & $X^{w}$ & $3.226 \pm 0.283$ & $3.314 \pm 0.034$ & $3.108 \pm 0.076$ & $3.216 \pm 0.103$ \\
& $Z^{\mathrm{NaCl}}$ & $0.074^{\mathrm{c}} \pm 0.006$ & $0.071^{\mathrm{ab}} \pm 0.010$ & $0.056^{\mathrm{a}} \pm 0.005$ & $0.066^{\mathrm{b}} \pm 0.011$ \\
\hline
\end{tabular}

Sampling times: 0, 15 and 30 days; $Z^{\mathrm{NaCl}}$ expressed as the $\mathrm{NaCl}$ concentration in the liquid phase; Values with no letters in the same row are significantly equal at a $p$ value $<0.05$; Values with different letters in the same row are significantly different at a $p$ value $<0.05$. 
Physicochemical changes during the different stages of dry cured lamb ham processing

Rada Bula, A. I. et al.

the inner zones, that is a counter-current flow controlling the chemical balance (BELLO GUTIERREZ, 2012). This study showed a distribution of water by depth (analysis by zones), showing a dynamic movement of the water on the inside of the meat piece. Both processes occurred simultaneously and were limited by the free water content in the meat piece, which depended on various factors such as the room conditions: temperature, pressure, moisture, air flow and the meat surface exposed (MUJUMDAR, 2006).

Also, during this process, each zone at each evaluation time presented significant differences in the parameter of $a_{w}(p<0.05)$ (Table 2$)$. This was consistent with the values for $Z^{\mathrm{NaCl}}$ reported for this stage, since the migration in each zone of the meat piece is not uniform.

\subsection{Drying-ripening}

The results showed there were no significant differences when comparing the salt concentrations $\left(Z^{\mathrm{NaCl}}\right)$ reached at the end of the process (3M and $6 \mathrm{M}$ of drying and ripening, as compared to zone $\mathrm{R}$ ), although there were significant differences $(p<0.05)$ for each time evaluated $0 / 3 \mathrm{M}, 1 / 3 \mathrm{M}, 2 / 3 \mathrm{M}, 3 \mathrm{M}$ and $0 / 6 \mathrm{M}, 2 / 6 \mathrm{M}$ and $4 / 6 \mathrm{M}, 6 \mathrm{M})$ during the process. The corresponded to an increasing trend for the salt concentration while $X^{w}$ and $a_{w}$ decreased. Tables 3 and 4 also showed a decrease in the $X^{w}$ values with processing time for both times tested (3M and 6M). During this stage the variables suggest a dehydration process, showing a behaviour similar to that reported by Albarracín (2009), Gou (1998) and Toldrá (2010) in Iberian dry cured hams, although they used another animal species.

Other variables such as $a_{w}$ presented values close to $0.995 \pm 0.008$ at the beginning of the process (control), which decreased with time to $0.748 \pm 0.008$ and $0.778 \pm 0.013$ for
3M and $6 \mathrm{M}$ respectively, values below 0.90 guaranteeing the microbiological stability of the meat product.

\subsection{Mass variation during the process}

The mass variation figure (Figure 2) was obtained by repeating the process using 0.7 days $/ \mathrm{kg}$ of salting and 15 days of post-salting, assayed two drying-ripening evaluation times ( $3 \mathrm{M}$ and $6 \mathrm{M}$ ). The results showed values close to $-0.0651 \pm 0.019$ and $-0.0759 \pm 0.008$ in the salting phase and $-0.169 \pm 0.009$ in the post-salting stage showing cumulative weight losses. The mass variation that takes place during the complete process corresponds to the mass balance, where there is a gain in the weight of salt by the meat piece during salting (ALIÑO et al., 2009b) and of some other soluble components (CORZO et al., 2014; THORARINSDOTTIR et al., 2004) and water losses during the post-salting and drying-ripening stages (higher in the drying- ripening stage than in the former) (ARNAU; MONFORT, 1998).

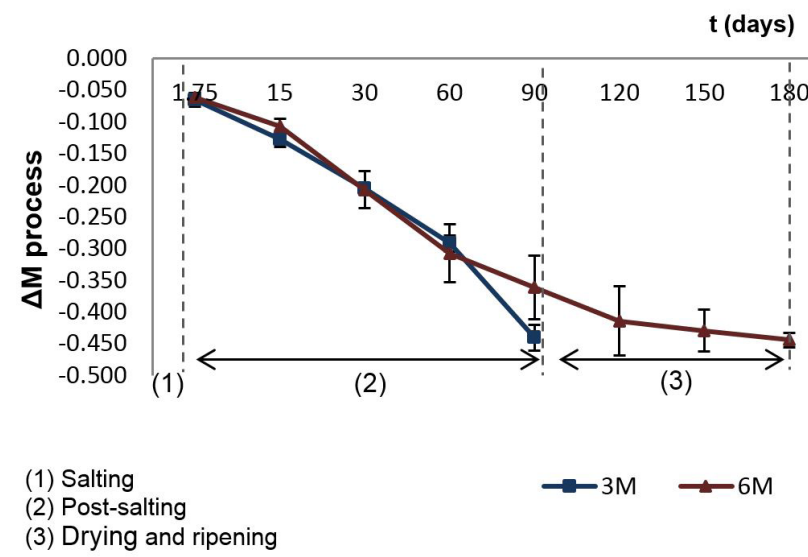

Figure 2. Mass variation during the lamb shank dry curing process.

Table 3. Physicochemical evolution during the 3 month drying-ripening stage - comparison with non-treated samples.

\begin{tabular}{|c|c|c|c|c|c|c|}
\hline \multirow{2}{*}{ Zone } & \multirow{2}{*}{ Parameters } & \multicolumn{5}{|c|}{ Sampling time } \\
\hline & & 0 & $0 / 3 \mathrm{M}$ & $1 / 3 \mathrm{M}$ & $2 / 3 \mathrm{M}$ & $3 / 3 \mathrm{M}$ \\
\hline \multirow{3}{*}{ R } & $a_{w}$ & $0.995^{d}$ & $0.923^{c}$ & $0.919^{c}$ & $0.905^{b}$ & $0.749^{a}$ \\
\hline & $X^{w}$ & $3.476^{d}$ & $3.097^{\mathrm{cd}}$ & $2.053^{b c}$ & $1.955^{b}$ & $0.789^{a}$ \\
\hline & $Z^{\mathrm{NaCl}}$ & $0.000^{a}$ & $0.097^{b}$ & $0.103^{b}$ & $0.120^{\circ}$ & $0.212^{d}$ \\
\hline
\end{tabular}

The values reported correspond to the mean values in Zone $\mathrm{R} ; \mathrm{Z}^{\mathrm{NaCl}}$ expressed as the $\mathrm{NaCl}$ concentration in the liquid phase; Values with no letters in the same row are significantly equal at a $p$ value $<0.05$; Values with different letters in the same row are significantly different at a $p$ value $<0.05$.

Table 4. Physicochemical evolution during the 6 month drying-ripening stage - comparison with non-treated samples.

\begin{tabular}{|c|c|c|c|c|c|c|}
\hline \multirow{2}{*}{ Zone } & \multirow{2}{*}{ Parameters } & \multicolumn{5}{|c|}{ Sampling time } \\
\hline & & 0 & $0 / 6 \mathrm{M}$ & $2 / 6 \mathrm{M}$ & $4 / 6 \mathrm{M}$ & $6 / 6 M$ \\
\hline \multirow{3}{*}{$\mathrm{R}$} & $a_{w}$ & $0.995^{\mathrm{e}}$ & $0.915^{d}$ & $0.893^{c}$ & $0.820^{b}$ & $0.778^{a}$ \\
\hline & $x^{w}$ & $3.476^{c}$ & $3.306^{c}$ & $2.161^{b}$ & $1.236^{\mathrm{ab}}$ & $1.016^{a}$ \\
\hline & $Z^{\mathrm{NaCl}}$ & $0.000^{a}$ & $0.072^{b}$ & $0.135^{\circ}$ & $0.193^{d}$ & $0.208^{d}$ \\
\hline
\end{tabular}

The values reported correspond to mean values in Zone $\mathrm{R} ; Z^{\mathrm{NaCl}}$ expressed as the $\mathrm{NaCl}$ concentration in the liquid phase; Values with no letters in the same row are significantly equal at a $p$ value $<0.05$; Values with different letters in the same row are significantly different at a $p$ value $<0.05$. 
Physicochemical changes during the different stages of dry cured lamb ham processing

Rada Bula, A. I. et al.

Comparing with the data reported for dry cured pork ham, mass variation during the post-salting stage can reach values of $10-15 \%$, corresponding to values of -0.100 to -0.150 (ARNAU; MONFORT, 1998). Values close to $10 \%$ have been reported for thawed dry cured ham made with Iberic pork (GRAU et al., 2008) and values higher than 22\% for Spanish ham (BARAT et al., 2005) during this phase of the process.

There are few reports concerning the mass variation in dry cured lamb or goat ham, although according to Toldrá (2014), $40 \%$ or -0.400 water losses (mass variation) have been reported in the Fenalår process (dry cured product made with lamb shanks originating from Norway). In the present study, the cumulative mass variation reached -0.440 and -0.444 respectively for the $3 \mathrm{M}$ and $6 \mathrm{M}$ samples. In this case, there were no significant differences between the evaluation times, suggesting that for this parameter, both 3 and 6 months are adequate to reach the ideal mass variation.

\section{Conclusions}

The physicochemical changes involved in the diffusion and osmosis processes occurring during the dry cured ham process were analysed, the results allowing for an understanding of the process when developed with lamb shanks, and also the effects of some of the conditions according to each stage, zone and time. According to this study, the results suggest that 0.7 days $/ \mathrm{kg}$ of salting; 15 days of post-salting and 3 months of drying-ripening are adequate to obtain a safe dry cured lamb shank ham in a short time. These results are comparable with studies reported in the literature for this kind of product.

Further studies are needed to determine the effects of the lipolytic and proteolytic processes that occur simultaneously, since the biochemical parameters contribute to determining the final processing conditions.

\section{Acknowledgements}

The authors are grateful for the support received from "Finca la Primavera" - Facatativá, Cundinamarca; Instituto de Ciencia y Tecnología de Alimentos (ICTA) - Universidad Nacional de Colombia (Bogotá); and the Genética Molecular Animal Research Group - Universidad Nacional de Colombia and Departamento Administrativo de Ciencia, Tecnología e Innovación (Colciencias) Jóvenes Investigadores e Innovadores 2012.

\section{References}

ALBARRACÍN, W. Salado y descongelado simultáneo en salmuera para la obtención de jamón curado de cerdo de raza ibérica. 2009. 221 f. Disertación (Doctorado en Tecnología de Alimentos)-Departamento en Tecnología de Alimentos, Universidad Politecnica de Valencia, Valencia, 2009.
ALIÑO, M.; GRAU, R.; BARAT, J. M.; BAIGTS, D. Influence of sodium replacement on the salting kinetics of pork loin. Journal of Food Engineering, v. 95, n. 4, p. 551-557, 2009a. http:// dx.doi.org/10.1016/j.jfoodeng.2009.06.016.

ALIÑO, M.; GRAU, R.; BARAT, J. M.; BLESA, E.; TOLDRÁ, F.; PAGÁN, M. J. Influence of sodium replacement on physicochemical properties of dry-cured loin. Meat Science, v. 83, n. 3, p. 423-430, 2009b. PMid:20416693. http://dx.doi.org/10.1016/j. meatsci.2009.06.022.

ALIÑO, M.; GRAU, R.; FUENTES, J.; BARAT, J. M. Influence of low-sodium mixtures of salts on the post-salting stage of dry-cured ham process. Journal of Food Engineering, v. 99, n. 2, p. 198-205, 2010. http://dx.doi.org/10.1016/j.jfoodeng.2010.02.020.

ARNAU, J.; GUERRERO, L.; CASADEMONT, G.; GOU, P. Physical and chemical changes in different zones of normal and PSE dry cured ham during processing. Food Chemistry, v. 52, n. 1, p. 63-69, 1995. http://dx.doi.org/10.1016/0308-8146(94)P4182-F.

ARNAU, J.; MONFORT, J. Tecnología de fabricación del jamón curado en distintos países. In: EL JAMÓN CURADO: TECNOLOGÍA Y ANÁLISIS DE CONSUMO: SIMPOSIO ESPECIAL ICONMST, 44., 1998, Madrid, Spain. Proceedings... Madrid: Editorial Estrategias Alimentarias, 1998. p. 9-21.

BARAT, J. M.; GALLART-JORNET, L.; ANDRÉS, A.; AKSE, L.; CARLEHÖG, M.; SKJERDAL, O. T. Influence of cod freshness on the salting, drying and desalting stages. Journal of Food Engineering, v. 73, n. 1, p. 9-19, 2006. http://dx.doi.org/10.1016/j. jfoodeng.2004.12.023.

BARAT, J. M.; GRAU, R.; IBÁÑEZ, J. B.; FITO, P. Post-salting studies in Spanish cured ham manufacturing: time reduction by using brine thawing-salting. Meat Science, v. 69, n. 2, p. 201-208, 2005. PMid:22062809. http://dx.doi.org/10.1016/j. meatsci.2004.05.020

BARAT, J. M.; GRAU, R.; PAGÁN-MORENO, M. J.; FITO, P. Replacement of pile salting by simultaneous brine thawing-salting in Spanish cured ham manufacturing. Meat Science, v. 66, n. 3, p. 603-608, 2004. PMid:22060870. http://dx.doi.org/10.1016/ S0309-1740(03)00176-1.

BELLO GUTIERREZ, J. Jamón curado: aspectos científicos y tecnológicos. España: Ediciones Diaz de Santos, 2012. 629 p.

BLESA, E.; ALIÑO, M.; BARAT, J. M.; GRAU, R.; TOLDRÁ, F.; PAGÁN, M. J. Microbiology and phisico-chemical changes of dry-cured ham during the pos-salting stage as affected by partial replacement of $\mathrm{NaCl}$ by others salts. Meat Science, v. 78, n. 1-2, p. 135-142, 2008. PMid:22062103. http://dx.doi.org/10.1016/j. meatsci.2007.07.008.

BOADAS, C.; GU, P.; VALERO, A.; ARNAU, J. Changes in different zones of dry-cured ham during drying. Fleischforschung Und Entwicklung, v. 1, p. 91-93, 2001. 
Physicochemical changes during the different stages of dry cured lamb ham processing

Rada Bula, A. I. et al.

CORZO, O.; BRACHO, N.; RODRIGUEZ, J. Predicción de los contenidos de agua y sal durante el salado de bagre usando diferentes mezclas salinas. Saber, v. 26, n. 3, p. 305-312, 2014.

FULLADOSA, E.; MUÑOZ, I.; SERRA, J.; ARNAU, J.; GOU, P. $X$-ray absorptiometry for non-destructive monitoring of the salt uptake in bone -in raw hams during salting. Food Control, v. 47, p. 37-42, 2015. http://dx.doi.org/10.1016/j.foodcont.2014.06.023.

GANIĆ, A.; ČAUŠEVIĆ, A.; KARAHMET, E.; STOJKOVIĆ, S.; RATKOVIĆ, D. Contribution to technology and quality ham sheep. In: INTERNATIONAL MEAT INDUSTRY CONFERENCE, 57., 2013, Belgrade, Serbia. Proceedings... Belgrade: Institute of Meat Hygiene and Technology, 2013. p. 347.

GOU, P. Dinámica del secado del jamón curado. In: ARNAU, J.; MONFORT, J. M. (Ed.). In: EL JAMÓN CURADO: TECNOLOGÍA Y ANÁLISIS DE CONSUMO: SIMPOSIO ESPECIAL ICONMST, 44., 1998, Madrid, Spain. Proceedings... Madrid: Editorial Estrategias Alimentarias, 1998. chap. 6, p. 89-106.

GRAU, R.; ALBARRACIN, W.; TOLDRÁ, F.; ANTEQUERA, T.; BARAT, J. M. Study of salting and post-salting stages of fresh and tawed Iberian hams. Meat Science, v. 79, n. 4, p. 677-682, 2008. PMid:22063029. http://dx.doi.org/10.1016/j.meatsci.2007.10.034.

INTERNATIONAL ORGANIZATION FOR STANDARDIZATION ISO. ISO-R 1442: meat and meat products: determination of moisture content. Geneva, 1973.

KRVAVICA, M.; FRIGANOVIĆ, E.; ĐUGUM, J.; KEGALJ, A. Dalmatinska kaštradina (koštradina). Meso: prvi hrvatski časopis o mesu, v. 11, p. 285-290, 2009.

MUJUMDAR, A. S. Drying of solids: principles, classification, and selection of dryers. In: HII, C. L.; ONG, S. P.; JANGAM, S. V.; MUJUMDAR, A. (Ed.). Handbook of industrial drying. 3rd ed. United States: Taylor \& Francis Group, 2006. 1312 p.

OPERTA, S.; SMAJIĆ, A.; TAHMAZ, J.; GANIĆ, A. Report: physicochemical and sensory properties sheep prosciutto produced traditional methods. In: SCIENTIFIC-EXPERT CONFERENCE OF AGRICULTURE AND FOOD INDUSTRY, 21., 2010, Neum, Bosnia. Proceedings... Sarajevo: Faculty of Agricultural and Food Sciences, 2010.
PALEARI, M. A.; MORETTI, V. M.; BERETTA, G.; CAPRINO, F. Characterization of a lamb ham: fatty acids volatile compounds composition. Journal of Muscle Foods, v. 17, n. 4, p. 398-412, 2006. http://dx.doi.org/10.1111/j.1745-4573.2006.00059.x.

SINHA, N. Handbook of food manufacturing. 2nd ed. Hoboken: John Wiley \& Sons, 2007. 2308 p.

STAMENKOVIĆ, T.; DEVIĆ, B. Senzorska svojstva ovčije stelje. Tehnologija Mesa, v. 47, p. 115-122, 2006.

STOJKOVIĆA, S.; GRABEŽB, V.; BJELANOVIĆB, M.; MANDIĆA, S.; VUČIĆA, G.; MARTINOVIĆC, A.; HÅSETH, T. T.; VELEMIR, A.; EGELANDSDAL, B. Production process and quality of two different dry-cured sheep hams from Western Balkan countries. Food Science and Technology, v. 64, n. 2, p. 1217-1224, 2015.

THORARINSDOTTIR, K.; ARASON, S.; BOGASON, S. G.; KRISTBERGSSON, K. The effects of various salt concentrations during brine curing of cod (Gadus morhua). International Journal of Food Science \& Technology, v. 39, n. 1, p. 79-89, 2004. http://dx.doi.org/10.1046/j.0950-5423.2003.00757.x.

TOLDRÁ, F. Dry cured products. Trumbull: Food \& Nutrition Press, 2002.

TOLDRÁ, F. Handbook of meat processing. Iowa: John Wiley \& Sons, 2010. $632 p$.

TOLDRÁ, F. Handbook of fermented meat and poultry. 2nd ed. Chennai: John Wiley \& Sons, 2014. 528 p.

TROEGER, S.; VESKOVIĆ-MORAČANIN, L.; TURUBATOVIĆ, M.; RISTIĆ, I. D. Traditionelle serbische Rohpökelwaren aus Rind- und Schaffleisch. Mitteilungsblatt Der Fleischforschung Kulmbach, v. 48, p. 115-121, 2009.

VILLALOBOS-DELGADO, L. H.; CARO, I.; BLANCO, C.; MORÁN, L.; PRIETO, N.; BODAS, R.; GIRÁLDEZ, F. J.; MATEO, J. Quality characteristics of a dry-cured lamb leg as affected tumbling after dry-salting and processing time. Meat Science, v. 97, n. 1, p. 115-122, 2014. PMid:24553493. http://dx.doi.org/10.1016/j. meatsci.2014.01.015. 